\title{
The Implications of Quantum Teaching Model by Combination of Write Stacking Notes and Passing of Idea Paper Techniques Compare With Expository Learning Model
}

\author{
Rose Rahmidani \\ Economics Education Department \\ Faculty of economics \\ Universitas Negeri Padang \\ Padang, Indonesia \\ rose_rahmidani@fe.unp.ac.id
}

\begin{abstract}
This research examines the differences in student learning outcomes using Quantum Teaching model by combination of write stacking notes and passing of idea paper techniques compare with the use of Expository Learning Model. This research determine the differences on students learning outcomes in introduction to management courses at Economics Education Department Faculty of Economics, State University of Padang. This research is a quasi experiment type. The population are students taking the Introduction to Management courses from January to June, 2016. This research used population research technique. Class $A$ as a experimental class taught using quantum teaching model and the class $B$ as a control class using expository learning model. There are 30 students in each class. Data analysis used normality test, homogeneity and hypothesis testing used $t$ test. The results of this research showed that (1) student learning outcome in the experimental class that taught by quantum teaching model (with an average score 82.19) is better than student learning outcome in the control class that used expository model (with an average score 74.30 ); (2) There are significant differences between student learning outcomes at the introduction to management courses using quantum teaching model compare with student outcome using the expository model at Economics Education Department, Faculty of Economics, State University of Padang. From the result concluded that quantum teaching models give the better value of learning process than ekspository model so lecture can use this models to other learning process in the classroom.
\end{abstract}

Keywords- Quantum Teaching Model, Write Stacking Notes, Passing Paper Idea Technique, Expository Learning Model

\section{INTRODUCTION}

The educational process is important in human life. Learning activities, which involving approaches and models of teaching and learning, is one of the basic elements of the educational process. It must be planned in systematic and applicable way. When it comes to learning, it is inseparable from the role and function of teachers. The quality learning can be embodied if teachers have required competencies. In summary, learning process is the ability of teachers to empower all elements that can influence the changes in student behavior. In fact, students have learning experience that is not always fun and interesting. Many complaints, such as the material are dull, dry, and learning just behind the desk, rigid, monotonous and very formal. It caused negative attitude and low learning outcomes. How to design an interesting learning? It is related to the approach or learning strategies. Related by learning teaching process, strategy of learning have a meaning as a general pattern of teacher and students activity on learning process to realize that goals.[1]

Faculty of Economics, State University of Padang (FE UNP), in accordance with its vision to become the competitive faculty in developing education and science in economics and business and its mission to organize higher education for vocational, academic and professional in the field of economics and business to create devoted, ethical, qualified, creative, innovative and globally competitive students. To achieve its vision and mission would not be easy; it demanded hard work and effort from all parties, including teachers and students. In order to produce intelligent students intellectually and emotionally so they would obtain a greater success requires educational process that enhances learning motivation and students' learning activities. Student motivation can be improve by variation of teaching method, giving the new stimulate example by give the question to students, used innovative and creative media and tools of learning for example figure, photo, video etc. [2]

The problems arise in Faculty of Economics for subjects which characteristics are conceptual and theories, such as Introduction to Management courses, where students tend to memorize the material. Yet the knowledge gained by the student exposes them to the real problem in learning, will make it easier for students to understand a concept than knowledge transferred just by lecturers. Understanding management broadly, should begin with capability of understanding the basic concepts contained in the courses. Success or failure of a student in understanding the management is determined by their understanding the concept in Introduction to Management course. So it's not surprising that the final grades/results of Introduction to Management course are still relatively low. Introduction to Management 
learning method has been done largely centered on lecturers using variety of learning methods. As the result, students become saturated during the lecture; they generally become inactive, and just listen and do the tasks assigned by the lecturers. This type of learning narrowing student opportunities and chances to issuing their ideas and creativity so they get bored quickly and not enthusiastic about this course. Moreover, students do not have small notes or summaries of lecture material to write the concepts of matter. Where as the used of summaries or notes could improve learning outcomes and student memory. The purpose of make a notes is a help to remind and repeat information, students just can remind a view of material in the learning process.[3]

The low learning outcomes of students in the course Introduction to Management could be seen in Table I.

TABLE I. LIST OF FINAL GRADES IN INTRODUCTION TO MANAGEMENT FACULTY OF ECONOMICS JANUARY-JUNE 2015 CLASS A

\begin{tabular}{|l|l|l|}
\hline No. & Final Grades & $\begin{array}{c}\text { Number of } \\
\text { Students }\end{array}$ \\
\hline 1 & A & 4 \\
\hline 2 & A- & 3 \\
\hline 3 & B + & 2 \\
\hline 4 & B & 5 \\
\hline 5 & B- & 5 \\
\hline 6 & C + & 4 \\
\hline 7 & C & 5 \\
\hline 8 & C- & 3 \\
\hline 9 & D & 2 \\
\hline 10 & E & 1 \\
\hline
\end{tabular}

From table I, it was concluded that only $56 \%$ of students who passed the course (theydo not need to retake the course) with grades A to B-, while the rest are in the category need to retake the course ( $\mathrm{C}$ to $\mathrm{E}$ ) as much as $44 \%$. Data from table 1 is an example of problems associated with low grades of student learning, but there are many more courses with the same issues in particular subjects with logical mathematical characteristics.

Learning outcomes are influenced by three factors: internal factors of the students, external factors outside the student and learning approaches [4]. At learning approach, the efforts to provide appropriate strategies and methods help to determine learning outcomes. One method that can be applied by lecturers to overcome this problem is to use the Quantum Learning method, a learning method that was developed by Bobby De Porter and Mike Hernacki. Quantum term borrows a term in physics, but the application of this method can be used by anyone and in a variety of subjects. The main principle of Quantum Learning is to bring the student into the world of teachers, and the ushering teachers to the world of students with main focus of the learning subject is the student [5]. Teachers as facilitators, so teachers need to understand the potential of students in advance. Quantum Learning, which further developed into Quantum Teaching is a way that teachers can do to improve student motivation, because it's creates a fun environment and process that produce successful learning [5]. Quantum Teaching methods is better than the conventional teaching methods to improve student learning outcomes [6]. Quantum Teaching methods consist of several parts: creating an exciting atmosphere, creating a dynamic teaching, creating excellent presentations, and create learning skills. Under these conditions, the teacher can use other methods with creating Quantum Teaching, such as create skills of study by using effective noting method (Write Stacking Notes) and combining with passing idea paper technique as closing learning. Some researches conclude that Effective Recording method, write stacking note can effectively improve students' creativity and mastery in learning [7].

Write Stacking Notes is an abbreviation of notes write and compose. Students can use the steps in writing of stacking notes to record all information and facts obtained during learning process. Write Stacking Notes is able to guide students to record and easier for students to remember material recorded from the projection of colors and interesting symbols that could make students eager and excited to look back at their notes. Write Stacking Notes is part of method contained in Quantum Teaching: which is Effective Recording Method. Write Stacking Notes stands to notes that written and composed. Write Stacking Notes used so the students can take advantage of the time and ability to reverie toward more productive / focused attention on the tasks they faces.

Based on the records that have been written and compiled, students presented the facts and develop the knowledge into paper idea that done alternately or passed. This technique known as passing idea paper technique. The use of passing idea paper in the closing lesson requires students to be more focused on lessons so at the end of day of learning, they can put forward their ideas on a piece of paper with the question about the principal subject matter. At the closing lessons, lecturer may use passing idea paper technique. This technique aims for students to understand the concept of subjects in more depth, able to find the facts, and develop their knowledge [8].

Quantum Teaching model as described above in this research will be compared with the results using Expository Learning model. Expository Learning Model is model to deliver the subject matter there in includes a mix of lectures, question and answer method, and the method of task [9]. Expository is a teaching model that aims to describe the teacher's knowledge about the material that has been prepared by teachers in a systematic and well prepared way, so in this model, the teacher explain to students about facts and important information.

Expository Learning model is a learning process that centered more to the teacher (teacher centered). Teachers are the primary source and giver of information. Although expository models use a combination of methods in addition to lectures, the emphasis remains on the admissions process knowledge (the subject matter) rather than on the search of process and construction knowledge. Learning with Expository Models will be more effective if teachers can reduce the amount of speech (the dominance of teachers is reduced), students are more active, adding another tool and balancing their performance by using other strategies. 
Based on research background, it is essential to learn studying with Quantum Teaching model, because it is an innovative and creative model that aims to create conducive environment and fun learning process resulting successful learning and enhance student motivation in learning.

\section{RESEARCH METHOD}

This type of research is quasi-experimental research. The research design is Randomized Group Only Post-test Design. Research population is students at Economics Education Department, Faculty of Economics, State University of Padang, taking the Introduction to Management course in the semester from January to June, 2016 at class A and class B with population research technique. Experimental class taught using Quantum Teaching model, a combination of effective noting method (write stacking note) and passing idea paper while the control class using Expository Teaching model. There are 30 students in each class. Data analysis technique used normality test, homogeneity test, and hypothesis testing using $\mathrm{t}$ test. Instruments used in this research were a form of cognitive aspects of student assessment of learning outcome with objective tests given at the end of the research.

\section{RESULTS AND DISCUSSION}

This type of research is quasi-experimental research. The research design is Randomized Group Only Post-test Design. In this design have a control class that have no use a special treatment but use a ekspository teaching and then for the experimental class thougt use quantum teaching model [10]. Design of research showed by the table II below:

\begin{tabular}{|l|c|c|}
\multicolumn{2}{|c|}{ TABEL II. RESEARCH DESIGN } \\
\hline \multicolumn{1}{|c|}{ Class } & Treatment & Posttest \\
\hline Experiment & $\mathbf{X}$ & $\mathbf{T}$ \\
\hline Control & - & $\mathbf{T}$ \\
& & \\
\hline
\end{tabular}

X: treatment that given to experimental class used by combination of writes stacking notes and passing of idea paper techniques.

T : Final Test appropriate with learning material.

TABLE III. HYPOTHESIS TESTING OF FINAL GRADES

\begin{tabular}{|l|l|l|l|}
\multicolumn{4}{c|}{ Descriptive statistics } \\
\hline Model & N & Mean & Std Deviation \\
\hline Experiment ( Quantum Teaching) & 30 & 82.19 & 7.09 \\
Control (Ekspository) & 30 & 74.30 & 8.79 \\
\hline
\end{tabular}

Based on the analysis shown in table IV, this research obtained an average value of 82.19 for experimental class and 74.30 for control class, and significant of 0.05 level. this mean the null hypothesis is rejected and the prevailing working hypothesis. It can be concluded that there are significant differences between the combinations of effective noting method with write stacking notes and passing ideas paper compare to Expository Learning model for learning outcomes in Introduction to Management course.

Based on data analysis, researchers make further discussion about the results of this research. Hypothesis tests shown the differences in learning outcomes of students who taught by effective noting method (write stacking notes) and passing ideas paper technique compare to students who taught by Expository Learning model in Introduction to Management course in the semester from January to June, 2016 on class A and class B. This is in line with research with the title "the difference in the application of Quantum Teaching method with conventional methods in student learning outcomes"[6].The previous research stated that learning outcomes are better with the implementation of Quantum Teaching method. Differences in learning outcomes can be seen from the average grades of the experimental class (82.19), while the average grades of the control class is 74.30. After being tested by $t$ test with significant level of 0.05 . Based on the result concluded that the hypothesis which states "there is a difference in student learning outcomes using a combination of effective noting methods (write stacking notes) and passing ideas paper technique compare to student learning outcomes using expository learning model" is accepted. This fact proves that the application of combination of effective noting method (write stacking notes) and passing ideas paper technique in Introduction to Management course was influencing the learning outcomes in cognitive domain.

The Results of this research also line with research the title " The Implementation Quantum Teaching Method of Graduate Through Up- Grade Hard Skill And Soft Skill”. The result showed that Quantum Teaching Method has optomal to up-grade student's soft skill.[11]. And another research entitled "Implementation Quantum Teaching Model to increase the Achievment Motivation Student"have a conclusion that the implementation of the Quantum model of effective teaching increases student achievement motivation class VIII-B SMP Negeri 2 Anjir Pasar on sound teaching materials [12], and other research with title "The Effect of Note Taking in Science Education Through The Mind Maping Technique on Students Attitudes, Academic Achievment and Concept Learning" Say that Any difference positif and significance on learning concept student, to overcome missunderstanding, academic accievment and attitude of note taking through mind maping technique.[13]

The higher results in experimental class compare to control class caused by the application of write stacking notes method that requires students to listen the lecturer explanation then recorded the subject matter into stacking notes. The use of write stacking notes will increase student activity in learning. Students are not passive in listening to lecturer but remained active by making small note about the material being taught. Writing stacking notes allows students to use a variety of colors, images, and symbols in the notes that will increase their interest to re-read their notes. The steps of Write Stacking Notes [9] are as follows: a) Setting up a pen, high lighter with quite varied color, b) Prepare a sheet of paper, c) Have students paint a vertical line (approximately $1 / 4$ of the upper right portion to form two columns), d) Marking the left with $\mathrm{T}$ (a place to write important information), and the right portion by symbol $\mathrm{S}$ (a place to write ideas association that arise in the brain), it could be a statement, question, or all of 
their reaction to what was heard or seen, e) Ask students to read what has been written and marks what considered important by the way of coloring or under scored with a colored pen or high lighter in accordance with their own creations. Protrusion colors and symbols make it easier to remember information.

More over, by learning the technique of passing paper idea, students have higher responsibility towards the tasks given to their discussion group and themselves when writing down group statement obtained on ideas paper. While making the ideas in the paper, students became more knowledgeable about the material they learn, because before making statements, they should learn the material first by making effective noting method (write stacking notes) to help them determine the key points in a lesson so that students would give serious attention to lecturer when they explaining the material. The steps to implementing passing idea paper technique are: a) Establish the students in groups according to many topics material to discuss, b) Setting empty paper, c) Ask students to write a topic that has been mentioned by lecturer to each group, d) Asking students to write what they know about the topic by writing the name of their group, give time to discuss each topic for about 2 minutes, e) After the time for the first session finished, pass the idea paper in turns (rotation), where the paper of group I would be passed to group II, paper of group II passed to group III and so on until each group getting a pass last idea paper, f) Group II reads the paper passed from group I and add anything they think is yet to be written by the first group and also attaching the name of their group, as well as other groups, g) Finally, each group receiving the last idea paper, looking for references from all of the statements listed in the idea paper that they gained, h) Writing pages / sources used as reference, i) Ask students to copy over all material that has been discussed earlier and packed later as exam preparation materials so when the exam students are not confused with the material that will be faced.

In implementing this passing idea paper technique, lecturer create each group consist of 4-6 people and given the same time for every recharging sheet of paper. If student in the classroom is too large, then make 2-3 large groups and each group was divided into several small groups consist of 4-6 people according to the number of topics being taught that day.

The advantages of effective noting method are students easier to remember and get new information about an issue considered at that time. When lecturer explains the material, students are active in writing the important points so it is easy for them to understand and remember the material in a long time. Then the student is able to address the emotions and help them understand the lesson. Students in making stacking notes included their note with expression, pictures and statements whether they understand and do not understand. At the end of the lesson, students can ask the lecturers back about the things that they did not understood which existing on the notes.[14]

Further advantage is this method able to make a constructive dream. This technique trying to occupy the mind and make the conscious mind so that it can be controlled.
Students can build their own thoughts then this thought can be recorded into the stacking notes so that students can answer critical questions from lecturer and other students. It also allows the students to recall ideas and special thoughts of the material they had learned, so it would increase their conceptual understanding and better learning outcomes.

Another advantage with the use of symbols in the notes will trigger ideas, reminded to lecturers' explanation and help students to recall the material. In addition, the provision of assessment or advice will enable students to assess their understanding or giving criticism and constructive suggestions in order to reach a wider understanding about the material.

The differences in mastery of material between the experimental class and control class in detail can be seen in the table IV.

TABLE IV.THE DIFFERENCES IN MASTERY OF MATERIAL BETWEEN EXPERIMENTAL CLASS AND CONTROL CLASS

\begin{tabular}{|c|c|c|c|c|c|}
\hline \multirow[b]{2}{*}{ Material } & \multirow[b]{2}{*}{ Main Topic } & \multicolumn{2}{|c|}{$\begin{array}{l}\text { Experimental } \\
\text { Class }\end{array}$} & \multicolumn{2}{|c|}{ Control Class } \\
\hline & & $\begin{array}{l}\text { Total } \\
\text { Score }\end{array}$ & $\begin{array}{l}\text { Perc } \\
\text { enta } \\
\text { ge }\end{array}$ & $\begin{array}{l}\text { Total } \\
\text { Score }\end{array}$ & $\begin{array}{l}\text { Perc } \\
\text { enta } \\
\text { ge }\end{array}$ \\
\hline \multirow[t]{4}{*}{$\begin{array}{ll}1 & \text { Planning }\end{array}$} & $\begin{array}{ll}1 & \begin{array}{l}\text { Types and forms } \\
\text { of planning }\end{array}\end{array}$ & 188 & $90 \%$ & 167 & $80 \%$ \\
\hline & $\begin{array}{ll}\text { The obstacle and } \\
2 & \begin{array}{l}\text { effectiveness in } \\
\text { planning activity }\end{array}\end{array}$ & 157 & $75 \%$ & 111 & $53 \%$ \\
\hline & $\begin{array}{l}\text { The relationship } \\
\text { between } \\
3 \text { planning and } \\
\text { other } \\
\text { management } \\
\text { function }\end{array}$ & 166 & $79 \%$ & 143 & $68 \%$ \\
\hline & $\begin{array}{ll}\text { Technique in } \\
\text { planning activity }\end{array}$ & 152 & $72 \%$ & 144 & $69 \%$ \\
\hline \multirow{5}{*}{ 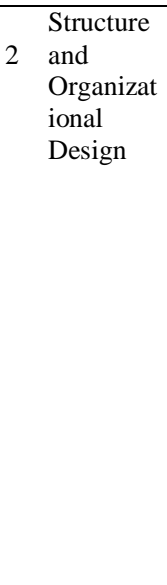 } & $\begin{array}{ll} & \begin{array}{l}\text { Definition of } \\
\text { organizational } \\
\text { structure }\end{array}\end{array}$ & 51 & $57 \%$ & 85 & $94 \%$ \\
\hline & $2 \begin{array}{l}\text { Design and chart } \\
\text { of organization }\end{array}$ & 76 & $84 \%$ & 72 & $80 \%$ \\
\hline & $3 \begin{array}{l}\text { Devise the } \\
\text { organizational } \\
\text { structure and } \\
\text { design }\end{array}$ & 119 & $79 \%$ & 130 & $87 \%$ \\
\hline & $4 \begin{array}{l}\text { Mechanistic and } \\
\text { organic structure }\end{array}$ & 85 & $94 \%$ & 84 & $93 \%$ \\
\hline & $\begin{array}{ll} & \text { Relationship } \\
\text { between } & \begin{array}{l}\text { coordination and } \\
\text { management }\end{array} \\
\text { range with } \\
\text { organizational } \\
\text { structure }\end{array}$ & 75 & $83 \%$ & 67 & $74 \%$ \\
\hline
\end{tabular}

Based on table IV, it can be seen the difference in mastery of each indicator in experimental class and control class. The total score is obtained from the total score of students answered correctly in one class in each indicator. If seen from grating matter, then the first indicator tested with 7 questions and number of students of one class is 30 students. The total maximum score for first indicator is $210(7 \times 30)$. Number of students with correct answers on this first indicator is 188 obtained from the sum score of question 1 to 7 . Having 
obtained a total score of the percentage level of student mastery in experimental class at first indication of this can be searched by dividing the total score to maximum score. Thus 188 divided by 210 , makes the mastery level on the first indicator of the experimental class in percent is $90 \%$.

On the first material, Planning Function, level of mastery in experimental class is higher than control class on every subject. The mastery in experimental classes ranging between $72 \%-90 \%$, while mastery in control class ranging between $53 \%-80 \%$. Based on these data we can conclude that the level of mastery in class taught by effective recording methods (write stacking notes) and passing idea paper technique on material planning functions better than the class taught by expository models.

On the second material, Structure and Organizational Design, level of mastery in control class is higher on the first and third subject (definitions of organizational structure and structure and organizational design). Mastery level reaches $87 \%-94 \%$. While the experimental class mastery level only $57 \%-79 \%$. For the second, fourth, and fifth subject, level of mastery in experimental class is higher compared with the control class. Mastery level ranges between $83 \%-94 \%$ while the control group only ranged between $74 \%-93 \%$. Based on the result can be concluded that the level of mastery in experimental class in most subjects in this second material, higher than the control class.

Overall it can be concluded the different levels of mastery of material for experimental class and control class. Implementation of effective recording method (write stacking notes) and passing idea paper technique on Introduction to Management course is very precise and gives a high level of mastery of the material so the students can improve their learning outcomes.

Therefore, the results of this research are expected to be a problem solving of low student learning outcomes. If lecturer usually only use monotonous and not varied learning methods, from now they should consider other methods of learning, such as effective noting method (write stacking notes) and passing idea paper technique. Based on this research, the student learning outcomes in experimental class is higher than the control class.

\section{IV.CONCLUSION}

Based on these results it can be concluded that the results of student learning outcome in experimental class (class A) on Introduction to Management course which used effective noting method (write stacking notes) and passing idea paper technique better than the results of student in control class (class B) which used expository learning model.
The average grade of student in experimental class is 82.19 and the average grade of student in control class is 74.30. There is a significant difference between the results of student learning in Introduction to Management course in experiment class (class A) which used effective noting method (write stacking notes) and passing idea paper technique compare to student results of student in control class (class B) which used expository learning model at the Faculty of Economics, State University of Padang. From the result concluded that quantum teaching models give the better value of learning process than ekspository model so lecture can use this models to other learning process in the classroom.

\section{ACKNOWLEDGMENT}

Thanks are due to Rector of State University of Padang, Prof. Ganefri have supported us to participate in this conference, Thank you.

\section{REFERENCES}

[1] Hamruni, 2012. Strategi Pembelajaran. Yugyakarta: Insan Madani

[2] Ahmad, Rohani, Ahmadi. 2007. Pengelolaan Pengajaran. Jakarta: Rineka Cipta

[3] Roestikawati,Teti.2008 Mind Mapping Dalam Metode Quantum Learning Pengaruhnya Terhadap Prestasi Belajar Dan Kreativitas Siswa.http://pkab.word press.com/2008/04/02/metode-quantumlearning/diunduh pada 15 Februari 2016

[4] Syah, Muhibbin. 2014. Psikologi Pendidikan. Bandung: PT Remaja Rosdakarya

[5] DePorter, B, Reardon Mark \& Nourie Sarak Singer. (2007) Mempraktikan Quantum Learning di Ruangan Kelas. Bandung: Kaifa.

[6] Prasetyani, Yekti. 2012. Perbedaan Penerapan Model Pembelajaran Quantum Teaching dengan Metode Konvensional dalam Hasil Belajar Siswa. Semarang. Economic Education Analysis Journal

[7] Kurniawati, Any. 2014. Penerapan Mind Mapping Dan Catatan Tulis Susun Terhadap Kreativitas Dan Ketuntasan Belajar. Semarang. Chemistry in Education

[8] Gunawan, Adi W. (2003). Genius Learning Strategy. Jakarta: Gramedia

[9] Sunaryo. 1989. Strategi Belajar Mengajar Dalam Pengajaran Ilmu Pengetahuan Sosial. Jakarta: DEPDIKBUD

[10] Sudjana. 2005. Metoda Statistika. Bandung: Tarsito

[11] Rachmawati, Rima. 2012. The Implementation Quantum Teaching Method Of Graduate Through Up-Grade Hard Skill and Soft Skill (Case Study on Management Accounting Class ) // Procedia-Social and Behavioral Sciences 57 (2012) 477-485. Published by Elsevier Ltd.

[12] Eriyanti,Mahrita, Suyidno, Suriasa .2014. Implementasi Model Quantum Teaching Untuk Meningkatkan Motivasi Berprestasi Siswa. Berkala Ilmiah Pendidikan Fisika Vol.2 no 2 Juni 2014

[13] Akinoglu,0.Yasar,Z.2007. The Effect of Note Taking in Science Education Through the Mind Maping Technique on Students Attitudes, Academic Achievment and Concept Learning. Journal of Baltic Science Education Vol 6 No 3 ISSN 1648-3898.

[14] DePorter, Bobbi dan Mike Hernacki. 2003. Quantum Learning: Membiasakan Belajar Nyaman dan Menyenangkan. Bandung: Kaifa. 